Cambridge University Press

978-1-107-05503-2 - The Dutch Revolt and Catholic Exile in Reformation Europe

Geert H. Janssen

Frontmatter

More information

\title{
The Dutch Revolt and Catholic Exile in Reformation Europe
}

The Dutch revolt of the sixteenth century sparked one of the largest refugee crises of Reformation Europe. This book explores the flight, exile and eventual return of Catholic men and women during the war. By mapping the Catholic diaspora across northern Europe, Geert H. Janssen explains how exile worked as a catalyst of religious radicalisation and transformed the world views, networks and identities of the refugees. Like their Protestant counterparts, the displaced Catholic communities became the mobilising forces behind a militant International Catholicism. The Catholic exile experience thus facilitated the permanent separation of the northern and southern Netherlands. Drawing on diaries, letters and evidence from material culture, this book offers a penetrating picture of the lives of early modern refugees and their agency in the Counter-Reformation.

Geert H. Janssen is Professor of Early Modern History at the University of Amsterdam. 


\section{Cambridge University Press}

978-1-107-05503-2 - The Dutch Revolt and Catholic Exile in Reformation Europe

Geert H. Janssen

Frontmatter

More information 
Cambridge University Press

978-1-107-05503-2 - The Dutch Revolt and Catholic Exile in Reformation Europe Geert H. Janssen

Frontmatter

More information

\section{The Dutch Revolt and Catholic Exile in Reformation Europe}

Geert H. Janssen

University of Amsterdam 
Cambridge University Press

978-1-107-05503-2 - The Dutch Revolt and Catholic Exile in Reformation Europe

Geert H. Janssen

Frontmatter

More information

\section{CAMBRIDGE}

\section{UNIVERSITY PRESS}

University Printing House, Cambridge CB2 8BS, United Kingdom

Cambridge University Press is part of the University of Cambridge.

It furthers the University's mission by disseminating knowledge in the pursuit of education, learning and research at the highest international levels of excellence.

www.cambridge.org

Information on this title: www.cambridge.org/9781107055032

(C) Geert H. Janssen 2014

This publication is in copyright. Subject to statutory exception and to the provisions of relevant collective licensing agreements, no reproduction of any part may take place without the written permission of Cambridge University Press.

First published 2014

Printed in the United Kingdom by Clays, St Ives plc

A catalogue record for this publication is available from the British Library

Library of Congress Cataloguing in Publication data

Janssen, Geert H.

The Dutch Revolt and Catholic exile in Reformation Europe / Geert H. Janssen, University of Amsterdam.

pages $\mathrm{cm}$

Includes bibliographical references and index.

ISBN 978-1-107-05503-2

1. Reformation - Netherlands. 2. Catholics - Religious identity-

Netherlands - History. 3. Religious refugees - Netherlands -

History. 4. Counter-Reformation - Netherlands. 5. Catholic Church -

Netherlands - History. I. Title.

BR305.3.J36 2014

$274.92^{\prime} 06-\mathrm{dc} 23$

2014010870

ISBN 978-1-107-05503-2 Hardback

Cambridge University Press has no responsibility for the persistence or accuracy of URLs for external or third-party internet websites referred to in this publication, and does not guarantee that any content on such websites is, or will remain, accurate or appropriate. 
Cambridge University Press

978-1-107-05503-2 - The Dutch Revolt and Catholic Exile in Reformation Europe Geert H. Janssen

Frontmatter

More information

For Arnoud 


\section{Cambridge University Press}

978-1-107-05503-2 - The Dutch Revolt and Catholic Exile in Reformation Europe

Geert H. Janssen

Frontmatter

More information 
Cambridge University Press

978-1-107-05503-2 - The Dutch Revolt and Catholic Exile in Reformation Europe Geert H. Janssen

Frontmatter

More information

\section{Contents}

List of maps, table and figures

page viii

Preface

ix

List of abbreviations

$\mathrm{x}$

List of governors-general in the Low Countries, 1559-1609

xi

Maps

Introduction

Part 1 Flight

1 Corpus christianum divided

2 Exodus

Part 2 Exile

3 Conditions of displacement

4 The Counter-Reformation of the refugee

5 International Catholicism

\section{Part 3 Return}

6 A new order: the Southern Netherlands

7 Negotiating diversity: the Dutch Republic 
Cambridge University Press

978-1-107-05503-2 - The Dutch Revolt and Catholic Exile in Reformation Europe

Geert H. Janssen

Frontmatter

More information

\section{Maps, table and figures}

\section{Maps}

1 Map of the Habsburg Low Countries, 1566.

2 Map of the Habsburg reconquista under

Alexander Farnese.

page xiii

3 Map of the Northern and Southern Netherlands, 1609.

\section{Table}

1 Urban growth in Holland

\section{Figures}

1 Private Altar of Sybrant Pompeiusz Occo and Lisbeth Jacobsdr Brouwer, c.1559. St Nicolaikirche, Kalkar.

2 Pieter Pietersz, Epitaph painting of the Bam family, c.1575. St Nicolaikirche, Kalkar.

3 Monstrance, c.1543. St Nicolaikirche, Kalkar.

4 Aertgen Claesz van Leyden, The Calling of St Anthony, 1530s. Rijksmuseum, Amsterdam.

5 Title page of Johannes Costerius, Institutio Necessaria, 1580. Universiteitsbibliotheek Leiden.

6 Title page of Christiaen van Adrichem, Martyrologium, 1575-81. Het Utrechts Archief.

7 Triptych with Christ at the cross, c.1593.

O.L.V. Kathedraal Antwerpen/Lukas-Art in Flanders.

8 Hendrik Florisz van Langren, Map of Holland with the coats of arms of Philip II, 1594. Maritiem Museum Rotterdam.

9 Epitaph painting of Jacob Buyck, 1599-1605.

Museum Ons'Lieve Heer op Solder, Amsterdam. 
Cambridge University Press

978-1-107-05503-2 - The Dutch Revolt and Catholic Exile in Reformation Europe

Geert H. Janssen

Frontmatter

More information

\section{Preface}

The idea to write a book about early modern exile first emerged when I emigrated from the Netherlands in 2005. In the following years, academic positions and visiting fellowships in the United Kingdom, Belgium and Germany enabled me to develop my ideas in stimulating international environments. In Cambridge in 2008/9 I was fortunate to teach a course on early modern refugees, which encouraged me to pursue a comparative approach to the topic. I eventually completed the book at Corpus Christi College, Oxford and I thank my colleagues there for their support. Living and working in different countries has been a real privilege, which has also made me more alert to the effects of migration and globalisation in our modern society. Hence, this book is about the experience of exile in a bygone age, but it is also informed by the thoughts and experiences of a travelling academic in the twenty-first century.

I am grateful to colleagues and institutions on both sides of the Atlantic for their support over the years. Special thanks go to the Netherlands Organisation for Scientific Research (NWO) for awarding me a postdoctoral Veni grant in 2007. Additional funding was provided by the History Faculty at Cambridge, the British Academy, the History Faculty at Oxford and Corpus Christi College, Oxford. Alastair Duke kindly commented on an earlier, draft version of the book and shared his English translations of the diary of Wouter Jacobsz. Judith Pollmann has been a source of inspiration from the start. I should also like to thank Erik Aerts, Marten Jan Bok, AnneLaure van Bruaene, Hans Cools, Liesbeth Corens, Diarmaid MacCulloch, Luc Duerloo, Eamon Duffy, Marianne Eekhout, Jim Gibbons, Katy Gibbons, Kees Gnirrep, Hanneke Grootenboer, Erika Kuijpers, Mary Laven, Anton van der Lem, Jan Machielsen, Guido Marnef, Johannes Müller, Henk van Nierop, Andrew Pettegree, Hilde de Ridder-Symoens, Lyndal Roper, Jay Sexton, Louis Sicking, Violet Soen, Andrew Spicer, Jasper van der Steen, Nick Terpstra, Johan Verberckmoes, Rienk Vermij and John Watts.

Parts of Chapters 2 and 4 were published previously in Renaissance Quarterly and The Fournal of Ecclesiastical History. I thank the University of Chicago Press and Cambridge University Press for their permission to use these texts in this book. 
Cambridge University Press

978-1-107-05503-2 - The Dutch Revolt and Catholic Exile in Reformation Europe

Geert H. Janssen

Frontmatter

More information

\section{Abbreviations}

$\begin{array}{ll}\text { ARAB } & \text { Algemeen Rijksarchief, Brussels } \\ \text { ARSI } & \text { Archivum Romanum Societatis Iesu, Rome } \\ \text { BMGN } & \begin{array}{l}\text { Bijdragen en Mededelingen betreffende de Geschiedenis der } \\ \text { Nederlanden }\end{array} \\ \text { BN } & \text { Biographie Nationale } \\ \text { CBL } & \text { Centrale Bibliotheek Leuven } \\ \text { DWf } & \text { Wouter Jacobsz, Dagboek van broeder Wouter facobsz, I.H. } \\ & \text { van Eeghen (ed.), 2 vols (Groningen: Wolters, 1959-1960). } \\ \text { EAD } & \text { Erfgoed Archief Delft } \\ \text { HAK } & \text { Historisches Archiv Köln } \\ \text { NA } & \text { Nationaal Archief, The Hague } \\ \text { OKKN } & \text { Oud-Katholieke Kerk Nederland } \\ \text { RAG } & \text { Rijksarchief te Gent } \\ \text { RAL } & \text { Regionaal Archief Leiden } \\ \text { SAA } & \text { Stadsarchief Amsterdam } \\ \text { SCf } & \text { Sixteenth Century fournal } \\ \text { TvG } & \text { Tijdschrift voor Geschiedenis } \\ \text { UA } & \text { Utrechts Archief } \\ \text { UBA } & \text { Universteitsbibliotheek Amsterdam } \\ \text { Weinsberg } & \text { Hermann Weinsberg, Die autobiographischen } \\ & \text { Aufzeichnungen Hermann Weinsbergs. Digitale } \\ & \text { Gesamtausgabe. }\end{array}$


Cambridge University Press

978-1-107-05503-2 - The Dutch Revolt and Catholic Exile in Reformation Europe Geert H. Janssen

Frontmatter

More information

Governors-general in the Low Countries, 1559-1609

$\begin{array}{ll}\text { 1559-67: } & \text { Margaret of Parma } \\ \text { 1567-73: } & \text { Don Ferdinand Alvarez de Toledo, duke of Alba } \\ \text { 1572-73: } & \text { Don Juan de la Cerda, duke of Medina Celi (designate) } \\ \text { 1573-76: } & \text { Don Luis de Requesens } \\ \text { 1576-78: } & \text { Don Juan of Austria } \\ \text { 1578-92: } & \text { Alexander Farnese, duke of Parma } \\ \text { 1592-94: } & \text { Peter Ernst of Mansfeld } \\ \text { 1594-95: } & \text { Ernest of Austria } \\ \text { 1595: } & \text { Pedro de Fuentes } \\ \text { 1596-98: } & \text { Albert of Austria } \\ 1598-1621 / 33: & \text { Albert of Austria \& Isabella of Spain (sovereigns) }\end{array}$


Cambridge University Press

978-1-107-05503-2 - The Dutch Revolt and Catholic Exile in Reformation Europe Geert H. Janssen

Frontmatter

More information

\section{Maps}


Cambridge University Press

978-1-107-05503-2 - The Dutch Revolt and Catholic Exile in Reformation Europe

Geert H. Janssen

Frontmatter

More information

Maps

xiii

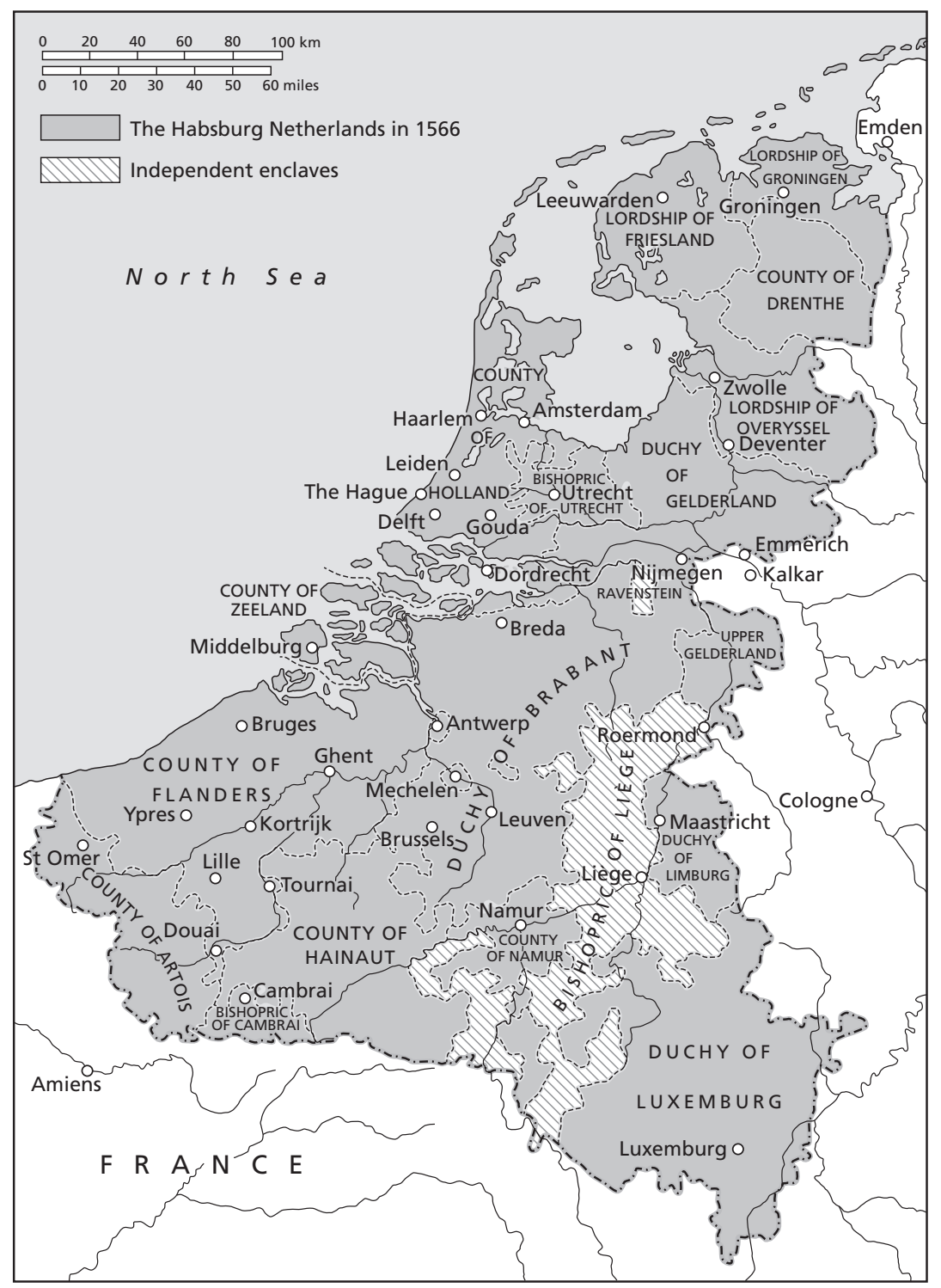

Map 1 Map of the Habsburg Low Countries, 1566 
Cambridge University Press

978-1-107-05503-2 - The Dutch Revolt and Catholic Exile in Reformation Europe

Geert H. Janssen

Frontmatter

More information

xiv Maps

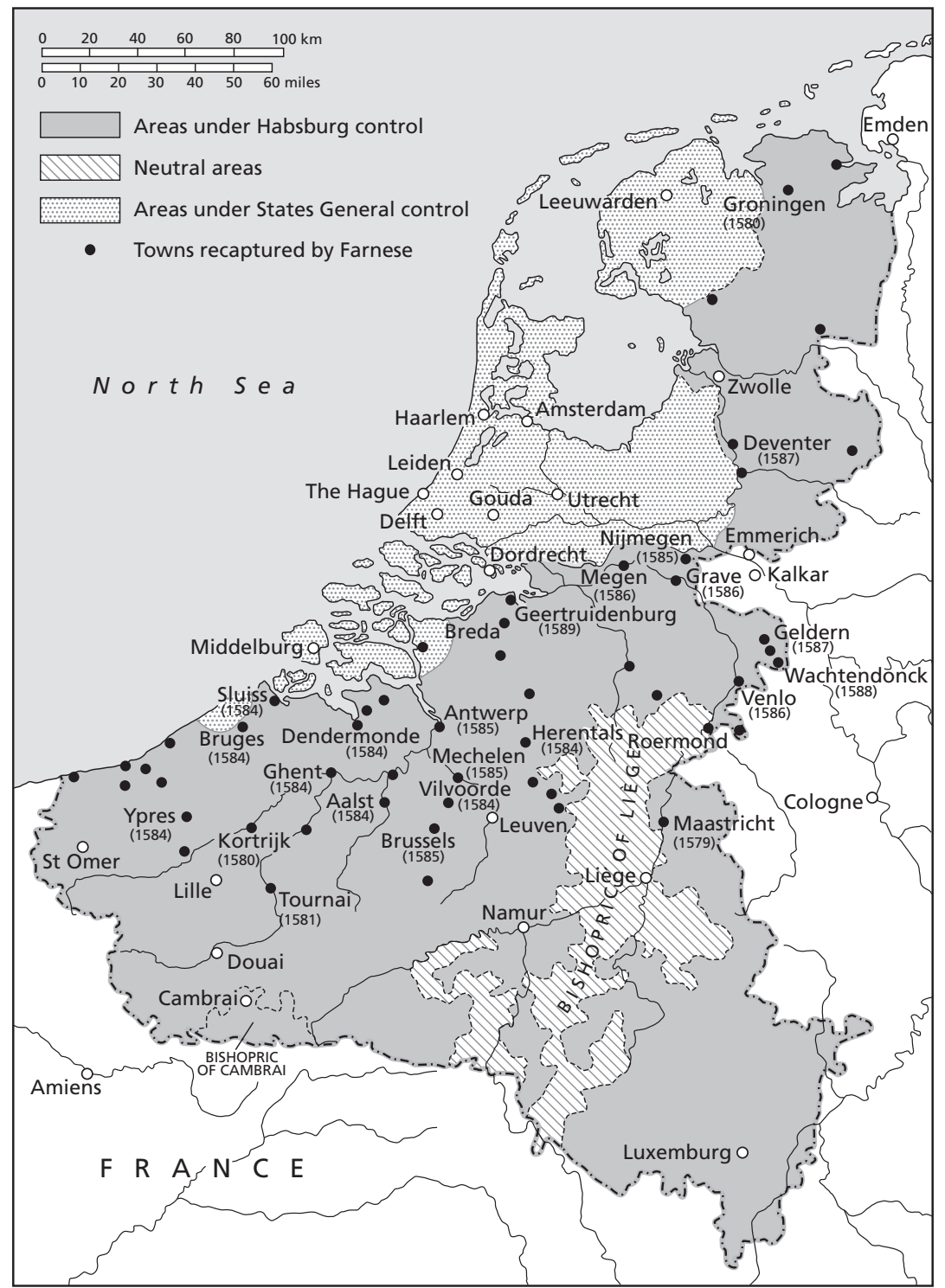

Map 2 Map of the Habsburg reconquista under Alexander Farnese 
Cambridge University Press

978-1-107-05503-2 - The Dutch Revolt and Catholic Exile in Reformation Europe

Geert H. Janssen

Frontmatter

More information

Maps

$\mathrm{xv}$

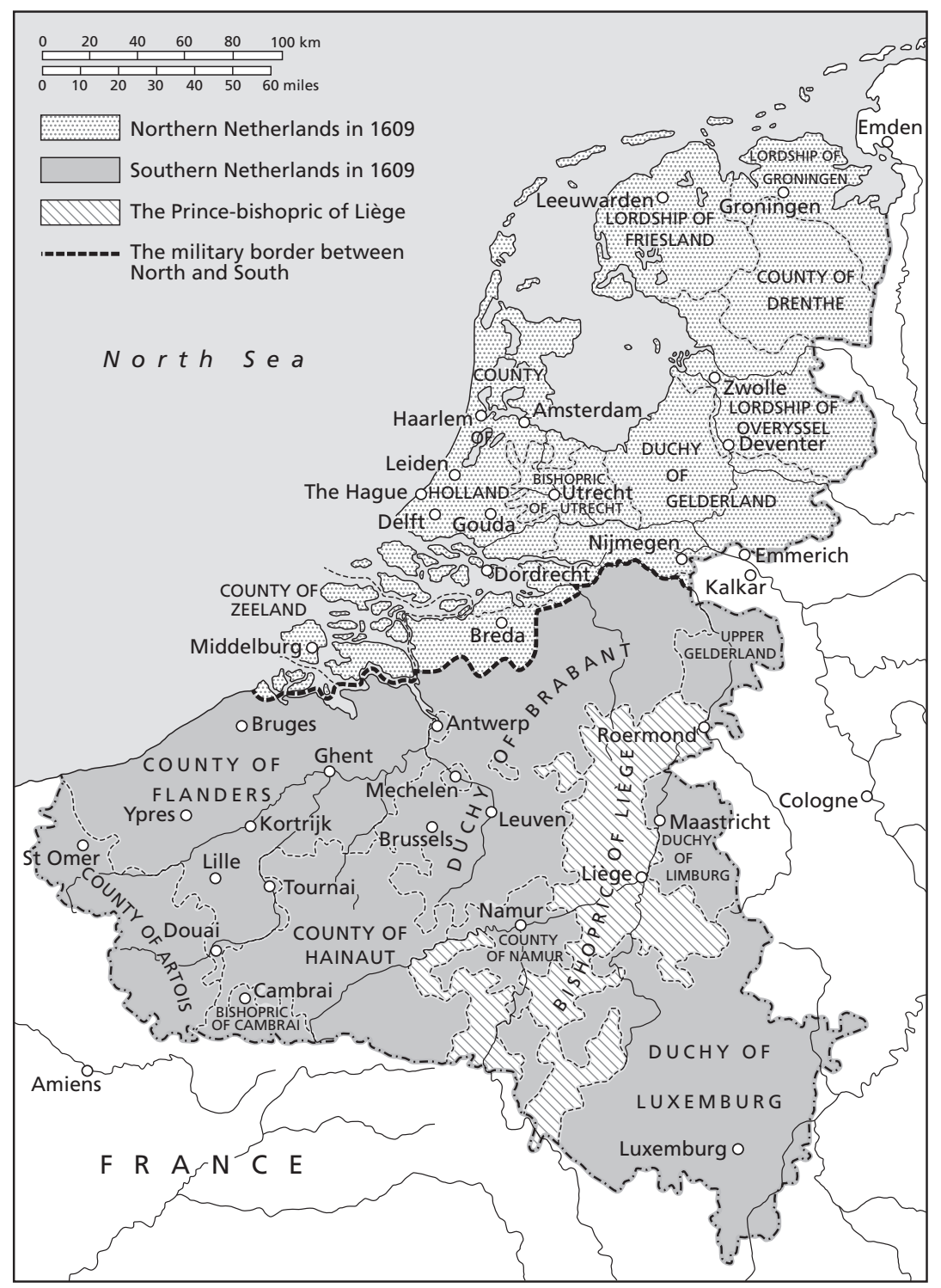

Map 3 Map of the Northern and Southern Netherlands, 1609 